\title{
16 Nisan 2017 Anayasa Değişikliği Referandumu Sürecinde Siyasal Bilgilenme ve Medya: Eğitim Düzeyine Göre Bir Karşıllaştırma
}

\author{
Şükrü Balcı (Prof. Dr.) \\ Şelçuk Üniversitesi İletişim Fakültesi \\ sukrubalci@selcuk.edu.tr \\ Orcid: 0000-0002-0477-0622 \\ Fadimana Tanacı \\ Selçuk Üniversitesi Sosyal Bilimler Enstitüsü \\ fadtnc@gmail.com \\ Orcid: 0000-0003-4552-2964 \\ Ayşe Nur Dağlı \\ Selçuk Üniversitesi Sosyal Bilimler Enstitüsü \\ ndagl194@gmail.com \\ Orcid: 0000-0002-1095-2051 \\ Esra Bayrak \\ Selçuk Üniversitesi Sosyal Bilimler Enstitüsü \\ esra_esrabayrak@hotmail.com \\ Orcid: 0000-0001-9494-3226
}

Başvuru Tarihi: 16.05 .2018

Yayına Kabul Tarihi: 06.09.2018

Yayınlanma Tarihi: 21.01.2019

Öz

Birey siyasal bilgilenme sürecinde, çeşitli faktörlerin etkisinde kalmaktadır. Günümüzde geleneksel medya araçlarının yanında yeni iletişim teknolojilerinin gelişimiyle bu süreç daha da çeşitlenmiştir. Söz konusu süreçte bireyler bir takım demografik özelliklerine göre farklı düzeylerde etkilenmektedir. Bu demografik özelliklerden biri de bireyin eğitim düzeyidir. Bu çalışmada da Konya'nın Selçuklu, Karatay ve Meram ilçelerinde ikamet eden insanların eğitim durumlarına göre siyasal bilgilenmesüreçlerinde iletişim araçveyöntemlerinin etkinliğiaçısındanfarklılıkların ortaya çıkarılması amaçlanmıştır. Saha araştırması yönteminin kullanıldığı bu çalışmada 600 kişiyle yüz yüze anket tekniği kullanılarak görüşülmüștür. Araştırma bulgularına göre katılımcıların siyasal bilgilenme sürecinde en çok etkilendiği medya türleri arasında televizyon ve internet ilk sıralarda yer almaktadır. Araștırma katılan seçmenlerin siyasal bilgilenme sürecinde interneti etkili görme eğilimi arttıkça, sosyal medyayı etkili görme eğiliminde de bir artış yaşanmaktadır. Yine eğitim düzeyi artışı, siyasal bilgilenmede gazete ve internetin etkili olduğunu düşünme yönündeki eğilimleri de artırmaktadır.

Anahtar Kelimeler: Siyasal Bilgilenme, Medya, Referandum, Etki, Eğitim. 
Research Article

\title{
Political Information and Media in The Referendum of the Constitutional Amendment 16 April 2017: A Comparison According to the Level of Education
}

\author{
Şükrü Balcı (Prof. Dr.) \\ Selçuk University Faculty of Communication \\ sukrubalci@selcuk.edu.tr \\ Orcid: 0000-0002-0477-0622 \\ Fadimana Tanacı \\ Selçuk University Institute of Social Sciences \\ fadtnc@gmail.com \\ Orcid: 0000-0003-4552-2964 \\ Ayşe Nur Dağlı \\ Selçuk University Institute of Social Sciences \\ ndaglı49@gmail.com \\ Orcid: 0000-0002-1095-2051 \\ Esra Bayrak \\ Selçuk University Institute of Social Sciences \\ esra_esrabayrak@hotmail.com \\ Orcid: 0000-0001-9494-3226
}

Date Received: 16.05 .2018

Date Accepted: 06.09.2018

Date Published: 21.01.2019

\section{Abstract}

The individual is under the influence of various factors in the process of political informing. Today, with the development of new communication technologies as well as traditional media tools, this process has become even more diverse. In the process, the individuals are affected at different levels according to some demographic characteristics. One of these demographic characteristics is the educational level of the individual. In this study, it was aimed to reveal differences in terms of the effectiveness of communication tools and methods in the political informing process according to the educational status of the people who reside in Selçuklu, Karatay and Meram districts of Konya. This field survey method was used and 600 people were interviewed using face-to-face survey technique. According to research findings, television and internet are among the first media types among the most influential participants in political informing process. As the tendency of the participating voters to influence the internet in the process of political information increases, there is an increase in the tendency to influence social media. The increase in the level of education also increases the tendency to think that the newspaper and internet is effective for political information.

Keywords: Political Information, Media, Referendum, Effect, Education. 


\section{Giriş}

Siyasal bilgilenme, bireyin yönetim alanından haberdar edilmesinin yanı sıra siyasal katılım sürecini etkilemektedir. Siyasal katılım sürecine etki eden siyasal bilgilenme, siyasi alana ilgi düzeyiyle yakından ilgilidir. Siyasal ilgi siyasal olayları, siyasal sistemin işleyişini ve siyasal kararların alınmasını sürekli ve düzenli olarak izleme eğilimidir. Siyasal olayları ve siyasal sistemin işleyiş̧ini sürekli ve düzenli olarak izleyen bir birey, izlemeyenlere oranla siyasal olaylar ve sistem hakkında daha fazla ve etraflı bilgiye sahip olur. Böylece siyasal ilgi hem doğrudan doğruya siyasal bilgilenmeyi belirler, hem de bireyin siyasal sisteme katılmasına katkı yapar (Kalaycığlu, 1983, 43).

Kalaycıoğlu'na $(1983,42)$ göre siyasal katılım noktasında ise bilgilenme bilişsel bir kolaylık veya hazırlık yaratarak siyasal katılmayı arttırmakta ve etkilemektedir. Öyle ki, bireyin siyasal bilgisi arttıkça başvurabileceği siyasal katılma türlerinin çeşit ve sayısı artabilecektir. Bireyin siyasal bilgisi ne denli fazla ise, birey sadece oy verme ile yetinmek gibi bir katılma türüne saplanıp kalmayacaktır.

Siyasal tercih sürecinde bireyin karar almasında siyasal bilgilenme etkili olmaktadır. Birey siyasal konuda seçme davranışı iki aşamalı bir süreçte gerçekleşmektedir. Birey siyasal alanda edindiği bilgi ile siyasal parti, aday veya diğer aktörlerin seçiminde oy kullanarak rol alıp almayacağına karar verir. Arkasından tekrar siyasal alanda edindiği bilgilere dayanarak bu kararı hangi yönde şekillendireceğine kararlaştırır. $\mathrm{Bu}$ noktada siyasal bilgilenme seçim sürecinde sandığa gidip gitmemeyi ve bireyin belirlediği bir parti veya adaya oy vermesi şeklinde ortaya çıkmaktadır (Gülmen, 1979, 18-21).

Ele alındığı üzere siyasal katılmayı arttırmanın başlıca unsurunu 'bilgi' oluşturmaktadır. Siyasal bilgi arttıkça hem siyasi kaynaklar çeşitlenmekte hem de siyasal katılım artmaktadır. Siyasal sistemin yapısı ve işleyişi hakkında bilgiye sahip olmadan, etkin bir siyasal katılımda bulunmak mümkün değildir (Özkan, 2004, 99).

Günümüzde siyasal bilginin yayılmasında medyanın ağırlığı günden güne artmaktadır. Zaman içerisinde medyanın sayısı ve türü arttıkça, yaşanan olaylar ve bunların izlenmesi arasındaki zaman süresinin azaldığı dikkat çekmektedir (Tokgöz, 2008, 378). Bu haliyle medya, kamu gündeminin belirlenmesinde ve insanlara referans olma açısından önemli bir konuma gelmiştir (Bekiroğlu ve Bal, 2014, 50). Medyadan yayılan siyasal bilgiler toplumun gündeminde yer alırken; aynı zamanda tartışmalara da yön vermektedir. Böylece kamuoyunda tartışılan konular daha fazla bilgi edinmeye zemin hazırlamış olur. Siyasal açıdan daha fazla bilgilenen bireyler, siyasal konularda daha bilinçli ve seçici olurlar. Siyasal bilgilenmeyle seçici olan birey, siyasal katılım ve karar verme noktasında daha rasyonel tercihler yapabilmektedirler (Arklan ve Karakoç, 2013, 333).

Bireylerin siyasal alanda yaşanan olaylardan haberdar olması, siyasal sürece ilgi ve katılım noktasında ayrıca siyasal toplumsallaşma da medya önemli bir role sahiptir. İletişim alanında yaşanan gelişmeler; gazete, sinema, radyo, televizyon ve internet yayınları medyayı siyasal olayların odağı haline getirmiştir. Seçim dönemlerinde ortaya çıkan zorlu rekabet koşulları siyasi partileri yeni arayışlara itmiştir. Seçmenleri ikna edebilmek siyasi parti ile ilgili bilgilerin onlara ulaştırılmasından geçer (Fidan, 2016, 21). Bu noktada siyasal bilgilendirmenin sağlıklı bir şekilde yapılabilmesi için 
de medyadan yararlanmak gerekir. Öyle ki; siyasi partiler amaçlarını gerçekleştirmek ve kendilerini tanıtmak böylece yine kendileri ile ilgili haber vermek ayrıca benzer siyasi aktörlerin mesajları hakkında bilgi almak üzere medyadan faydalanırlar (Aziz, 2003, 43). Bu haliyle demokratik bir toplumda haber medyasının temel işlevlerinden biri, vatandaşlarını bilgilendirmektir. Söz konusu işlev medyayı, seçmenlerin rakip partilerin ve adayların siyasi meseleleri ve platformlarını bilmesi gerektiğinde ve seçim kampanyaları sırasında daha da önemli hale getirmektedir (Dimitrova, 2014, 98). Aynı zamanda demokrasilerde yurttaşların doğru seçim yapabilmesi, medya yoluyla doğru bilgi edinmelerine de bağlıdır (Kışlalı, 2000, 24).

Medya yayınlarına maruz kalmak, bireyin çevresindeki olaylar hakkında olduğu kadar çevresinin yapısı ve kapsamı hakkında da temel bilgi ve algılarının belirlenmesini temin eder. Birey ulusal ve uluslararası siyasal sistemlerin varlığından haberdar oluşunu ve bu sistemlerin nasıl ilişkiler içinde olup ne tür işlevlere sahip oldukları hakkındaki bilgisini kitle iletişim araçlarının yayınları ile öğrenmektedir. Bu noktada özellikle göze ve kulağa hitap edebilen medya türleri, eğitim düzeyi yeterli olmayan geniş kitlelere bilgi sunma açısından, eğitim kadar etkili olabilecek, siyasal ilgi ve bilgi kaynağı olușturabilmektedir (Kalaycıoğlu, 1983, 33).

Siyasal iletişim alanındaki birçok çalışma, medyanın seçimler, adaylar, imajlar ve buna bağlı olarak seçim kampanyaları, partiler, programlar, vaatler, tartışmalar, siyasal skandallar, kamuoyu araștırmaları ve tahminlerin sonuçları gibi konularda toplumu bilgilendirme işlevi gördüğünü değerlendirmektedir. Seçmen kitleler, siyasal alandaki faaliyetleri, gelişmeleri, tartışmaları gündemleri medyanın diliyle kavrar hale gelmiştir (Damlapınar ve Balcı, 2014, 44). Yani doğrudan bilgi sahibi olmamakta, medyanın kendilerine hazırladığı imajlar aracılığıyla fikir edinebilmektedirler.

İşte bu çalışma; 16 Nisan 2017 Anayasa Değișikliği Referandumu sürecinde Konya merkezde yaşayan seçmenlerin siyasal bilgilenmelerinde medyanın etkinliğini ortaya koymayı ve aynı zamanda eğitim düzeyine göre karşılaştırma yapmayı amaçlamaktadır. Bu amaca uygun olarak Konya'da yaşayan seçmenler içerisinden bir örneklem oluşturulmuş ve veriler toplanmıştır.

\section{Siyasal Bilgilenmede Medyanın Rolü}

Toplumların ortak değerlerinin oluşturulmasında ve korunmasında en önemli öğelerden biri kuşkusuz medyadır (Kışlalı, 2002, 121). Demokratik toplumlarda medya; toplumun bilgilenme ihtiyacının giderilmesi, demokratik kültürün geliştirilmesi ve halka benimsetilmesi, toplumsal sorunlara yönelik halkın ilgi ve duyarlılığının artırılması, siyasal katılımın özendirilmesi ve bu doğrultuda kamu seferberliğinin sağlanması noktasında büyük görevler üstlenmektedir. Özellikle seçim atmosferi gibi insanların yoğun enformasyon bombardımanına uğradığı bir zamanda, medya aracılılığıyla sunulan bilgi, insanların uyarılması, siyasal tutum ve davranışlarının oluşmasında önemli bir etkiye sahiptir (Balcı, 2016, 103).

Medya, partiler ve adaylar için özellikle seçim dönemlerinde, kendilerini tanıtmak ve partilerin politikalarını seçmenlere açıklamak için önemli bir araçtır. Medya, seçim dönemlerinde siyasi partiler ve adayları daha fazla ön plana çıkartırken; aslında bir yandan da bireylerin bilgi edinme ihtiyaçlarını karşılamaktadır. Bireyler özellikle seçim dönemlerinde medyanın dolayımından geçen enformasyonlara maruz kalsalar da sonuç itibariyle siyasal bilgilenme hayatın her anında devam eden bir süreçtir (Balcı, 2016, 115). 
Siyasal bilgilenme ve siyasal katılım sürecinde medyanın oynadığı önemli rol üzerine uzun yıllardır tartışmalar devam etmektedir. Söz konusu tartışmalarda medyanın günden güne insanların yaşamına daha çok nüfus ettiği, inanların medyayla daha çok zaman geçirdiği, toplumsal ve siyasal yaşama ait gelişmeleri öğrenmede daha çok medyaya yöneldiği şeklindeki görüşlerde medyanın gücüne ve önemine vurgu yapılmaktadır (Balcı vd., 2013, 217-218).

İletişim alanındaki teknolojik gelişmeler; gazete, sinema, radyo, televizyon ve internet yayınlarının eklenmesi medyayı siyasal olayların odağı yapmıştır. Günümüzde gündem ve siyasal gündeme ilişkin bireylerin bilgi edinme aracı olarak yoğun şekilde medyayı kullanması; medyaya vazgeçilmez, neredeyse olmazsa olmaz bir özellik kazandırmıștır. Kitle iletișim araçlarının yayınlarına maruz kalan bireyler, dünyada ve ülkesinde nelerin olup bittiğini öğrenmek, sosyal olaylar hakkında bilgi edinmek isterler. Temel bilgi ve algllarının belirlenmesinde ya bütünüyle ya da kısmen kitle iletişim araçlarından etkilenirler (Arklan ve Karakoç, 2013, 327).

Uluslararası literatür incelendiğinde; geleneksel haber medyasının siyasal bilgilenme üzerindeki olumlu etkileri çeşitli araştırmalarla ortaya konulmuştur (Becker ve Dunwoody, 1982; Chaffee et al, 1994; Zhao ve Chaffee, 1995; Bolce et al, 1996; Chaffee ve Frank, 1996; Drew ve Weaver, 1998; Scheufele, 2002; Eveland, 2004; Wei ve Lo, 2008). Türkiye'deki literatür incelendiğinde de siyasal bilgilenme ile medya arasındaki ilişkiyi ortaya koyan nispeten daha sınırlı araştırma bulunmaktadır. Örneğin Ankara'nın Keçiören ilçesinde medyanın enformatik anlamda siyasal gücünün betimlendiği bir araştırmanın bulgularına göre; gazete okuma sıklığı arttıkça, siyasal haber ve yorumlara olan ilgi artmaktadır. Bu ilgi hem gazete okuma alışkanlığı hem de siyasi haber ve yorumları okuma alışkanlığı açısından erkeklerde ve üniversite mezunlarında daha yüksektir. Buna karşılık ögrrenim düzeyi düştükçe, günlük televizyon izleme süresi artış göstermektedir (Güneș, 1996, 821-822).

Güz (1995, 127-128) 1994 Yerel Seçimleri öncesi Ankara merkezde yaptığı araştırmasında televizyonun; siyasi kanaatler oluşurken başvurulan en önemli medya olduğuna vurgu yapmaktadır. Yazara göre eğitim seviyesi yükseldikçe televizyondan etkilenme oranı düşmekte, gazetelerden etkilenme oranı ise yükselmektedir.

Konya'da üniversite gençliğinin örneklem olarak seçildiği bir araştırmanın sonuçları ise, katılımcıların seçim döneminde bilgilenme ve rehberlik motivasyonu doğrultusunda interneti daha çok kullandıklarına vurgu yapmaktadır (Balcı ve Tarhan, 2007, 328-330).

Balcı ve Akar'ın (2010, 301) 29 Mart 2009 Yerel Seçimleri sırasında Konya'da yürüttükleri araştırmanın sonuçları; siyasal bilgilenme açısından televizyon ve gazetenin gücüne vurgu yapmaktadır. Partileriyle güçlü bağlar kuran seçmenler, destekledikleri partinin faaliyetleri ile ilgili daha çok bilgi arayışı içerisine girmekte ve bu amaçla televizyon ve gazetelere yönelmektedirler. Öyle ki; insanların parti bağımlılığı arttıkça, seçim dönemi gibi enformasyonun yoğun bir şekilde dolaşıma sokulduğu bir zamanda, siyasal bilgilenme amaçlı gazete yayınlarını önemseme eğilimleri de artmaktadır.

Elazığ örneğinde yürütülen bir araştırmanın bulguları da medyanın siyasal karar sürecindeki etkinliğini ortaya koymaktadır. Çalıșmada televizyon ve gazetelerde yayınlanan haberlerin, siyasi tercihler üzerindeki etkisi tespit edilmiştir. Özellikle 
gazetelerde yayınlanan haber ve köşe yazıları, siyasi tercihlerin oluşmasında önemli yere sahiptir (Doğan ve Göker, 2013a, 55).

Yine Doğan ve Göker'in (2013b, 123-125) 2011 Genel Seçimleri sırasında Elazı̆̆ örneğinde 1060 katılımcıdan elde ettikleri veriler incelendiğinde; eğitim durumu değişkenine bağlı olarak, yerel medyanın seçmen tercihi üzerindeki etkisi anlamlı bir şekilde farklılaşmaktadır. Buna göre, eğitim düzeyi arttıkça, yerel medyanın seçmenlerin tercihini etkilediğine ilişkin düşüncenin de arttığı dikkat çekmektedir.

Üniversite öğrencilerinin katıldığı bir araştırmanın sonuçlarına bakıldığında; siyasal bilgilenme bakımından en çok önem verilen medya türleri içerisinde gazete, televizyon ve internet ilk üç sırada yer almaktadır. Cinsiyet açısından kadınlar, erkeklere göre siyasal bilgilenme için televizyondan daha çok yararlanmaktadırlar. Yine parti bağlılığı güçlü olanlar, parti bağlılığı zayıf olanlara göre siyasal bilgilenme amacıyla daha fazla televizyon karşısına geçmektedirler (Balcı ve Bor, 2015, 67-68).

Balcı ve arkadaşlarının $(2016,124)$ Konya'da yaptı̆̆ı, "Siyasal Bilgilenmede Medyanın Rolü ve Etkinliği, Üniversite Öğrencileri Araştırması" isimli çalışmada, öğrencilerin siyasal bilgilenme süreçlerinde internet, sosyal medya ve televizyonu daha etkili gördükleri sonucuna ulaşılmıştır.

Siyasal bilgilenmede televizyonun etkilerinin konu edildiği bir yüksek lisans tezinde ise, Konya'daki seçmenlerin medya içerisinde en sık kullandıkları aracın televizyon olduğu ortaya konulmaktadır. Yine bu çalışmada araștırmaya katılan insanların orta düzey parti bağlılığına sahip olduğu ulaşılan bir diğer sonuçtur. Yapılan analizler sonucunda eğitim durumuna göre eğitimsizler en fazla parti bağlılığına sahipken; bunu ortaokul mezunları izlemektedir (Koçak, 2014, 160-161).

İşte yukarıda ortaya konulan literatür ışığında bu araştırmada aşağıda sıralanan araştırma sorularına cevap aranmaktadır,

- A.S. 1: Katılımcıların oy verme davranışlarında etkili olan faktörler nelerdir?

- A.S. 2: Katılımciların 16 Nisan 2017 Referandumu'ndaki siyasal karar verme süreçlerinde, medyanın etki düzeyi nedir?

- A.S. 3: Siyasal bilgilenmede medya türlerinin etki düzeyi ile siyasal kampanya ve konulara ilgi arasında nasıl bir ilişki vardır?

- A.S. 4: Siyasal bilgilenmede medya türlerinin etki düzeyi ile parti bağlılığı arasında nasıl bir ilişki vardır?

- A.S. 5: Siyasal bilgilenmede medya türlerinin etki düzeyleri arasındaki nasıl bir ilişki vardır?

- A.S. 6: Katılımcıların eğitim durumuna göre, siyasal bilgilenmede medya türlerinin etki düzeyinde bir farklılık var mıdır?

\section{Yöntem}

$\mathrm{Bu}$ çalışmada yöntem olarak saha araştırması kullanılmıştır. Konya'nın Selçuklu, Meram ve Karatay ilçelerinde yapılan çalışmada; her ilçeden 200 kişi olmak üzere toplamda 600 kişi ile görüşülmüştür. Katılımcıların siyasal bilgilenme süreçlerinde, eğitim durumuna göre medyanın etkinliğindeki farklılıkları ortaya koymak amacıyla veriler toplanmıştır. 


\subsection{Araştırmanın Uygulanması ve Örneklem}

Konya'da yaşayan insanların siyasal bilgilenme süreçlerinde eğitimin rolünü belirlemek amacıyla dizayn edilen bu araştırmanın evrenini; Konya'nın Selçuklu, Karatay ve Meram ilçelerinde yaşayan seçmenler oluşturmaktadır.

Örneklemin belirlenmesinde ise rastlantısal örneklem alma tekniği kullanılmıștır. Araştırmada elde edilen veriler, katılımcılarla yüz yüze görüşmeye dayalı anket tekniğiyle toplanmıştır. Yapılan değerlendirmeler sonucunda 600 anket analize tabii tutulmuştur.

\subsection{Veri Toplama Araçları}

Araștırmaya katılanlara siyasal bilgilenme süreçlerinde eğitimin etki düzeyini ortaya koymak amacıyla 28 sorudan oluşan bir anket formu hazırlanmıştır. Anket formu katılımcılar tarafından anlaşılabilecek şekilde, konu ile ilgili yapılmış araştırmalardan faydalanılmıștır (Balcı ve Akar, 2010; Balcı, 2016). Anket formunun ilk bölümünde katılımcıların oy verme davranışlarında hangi faktörlerin etkili olduğunu ölçmek amacıyla 5'li likert tipinde hazırlanmış 15 soruya yer verilmiştir. Katılımcılardan "1= Çok etkisiz, $5=$ Çok etkili” aralığında cevaplar alınmıştır. Ölçeğin güvenilirlik oranını hesaplamada Cronbach's Alpha değeri ,85 olarak tespit edilmiștir.

Anketin ikinci bölümünde, katılımcılardan oy vermeyi düşündükleri partiye bağlılık derecelerini belirtmeleri için " $1=$ Çok zayıf, $10=$ Çok güçlü” aralığında cevapları işaretlemeleri istenmiştir. Yine ülke sorunlarına karşı ilgi düzeyleri ile seçim dönemlerinde siyasal kampanya ve konulara ilgi düzeylerini ölçmek amacıyla araştırmaya katılanlardan, "1= Hiç ilgilenmem, 10= Çok ilgiliyim" aralığında cevap vermeleri istenmiștir.

Anket formunun üçüncü bölümünde 16 Nisan Referandumu'nda katılımcıların siyasal bilgilenme süreçlerinde, medya türlerinin etkinliğini ortaya koymak üzere 5 likert tipinde 5 sorudan oluşan bir ölçek kullanılmıştır. Ölçekte katılımcılardan "1= Çok etkisiz, 5= Çok etkili” aralığında cevaplar alınmıştır. Ölçeğin güvenilirlik katsayısı Cronbach's Alpha= ,81'dir.

Anket formunun son bölümünde demografik özelliklerin belirlenmesi amaciyla çeşitli sorular sorulmuştur.

\subsection{Verilerin Analizi ve Kullanılan Testler}

Saha araştırması 5-15 Nisan 2017 tarihleri arasında katılımcılarla yüz yüze görüşme yoluyla gerçekleştirilmiştir. Elde edilen veriler, istatistik programı kullanılarak elektronik ortamda işlenmiştir. Verilerin analizinde; katılımcıların demografik özellikleri ile siyasal tutum ve davranışlarına ilişkin bir takım veriler elde etmede Frekans Analizi ve Betimleyici İstatistikleri esas alınmıştır. Siyasal bilgilenmede medya türlerinin etki düzeyi ile siyasal kampanya ve konulara ilgi ve parti bağlılığı arasındaki ilişki Korelasyon Analizi ile ortaya konulmuştur. Eğitim durumuna göre siyasal bilgilenmede medya türlerinin etki düzeyindeki farklılıkları belirlemede Tek Yönlü Varyans Analizi (ANOVA) kullanılmıştır.

\subsection{Araştırmanın Modeli}

$\mathrm{Bu}$ araştırma genel tarama modelinde olup; çalışmanın bağımlı ve bağımsız değişkenleri arasında karşılaștırmalı ilişkisel tarama yapılmıștır. On sekiz ve seksen sekiz yaş aralığına sahip olan katılımcıların, siyasalbilgilenmelerinde 
medyanın etkinliği ile eğitim düzeyine göre karşılaştırmalar ortaya konulmak istenmiştir.

\section{Bulgular ve Yorum}

$\mathrm{Bu}$ başlık altında ilk olarak katılımcıların sosyo-demografik özellikleri ortaya konulmakta; siyasal tutum ve davranışları mercek altına alınmaktadır. Sonrasında siyasal bilgilenmede medya türlerinin etki düzeylerine ilişkin değerlendirmelere yer verilmektedir.

\subsection{Sosyo-Demografik Özellikler}

- Katılımcıların yüzde 52'si erkek, yüzde 48'i kadınlardan oluşmaktadır. Oranlar karşılaştırma yapmak için yeterlidir.

- Medeni duruma bakıldığında araştırmaya katılanların yüzde 55,2'si evliyken; yüzde 44,8'i bekârdır.

- Araştırma sorularına cevap verenlerin yaşının betimleyici istatistik sonuçları incelendiğinde en düşük 18, en yüksek 88 yaşındaki katılımcılarla görüşüldüğü dikkat çekmektedir. Katılımcıların yaş ortalamaları ise 34,46 'dır.

- Katılımcıların meslek dağılımlarına bakıldığında yüzde 27,5'inin öğrenci olduğu görülmektedir. Yüzde 14,7'si memurken; yüzde 14,3'ü ev hanımıdır. Diğer dağılımlar ise şu şekilde sıralanabilir: Yüzde 12'si işçi, yüzde 9,5'i esnaf, yüzde 7,7'si serbest meslek, yüzde 6,2'si diğer, yüzde 6'sı emekli ve yüzde 2,2'si sanayici-tüccardır.

- Eğitim düzeylerine bakıldığında sonuçlar şu şekildedir: Yüzde 41,7'si lise, yüzde 34,8'i üniversite, yüzde 11,2'si ilkokul, yüzde 7,8'i ortaokul, yüzde 4'ü lisansüstü ve yüzde 0,5'i okuryazardır. Araștırmaya katılan seçmenler arasında lise ve üniversite mezunları çoğunluğu oluşturmaktadır.

- Katılımcıların gelir dağılımı en düşük500 TL ve en yüksek 70 bin TLaralığındadır. Gelir ortalamaları ise yaklaşık 3380 TL'dir.

\subsection{Siyasal Tutumlar}

Siyasal tutumlar başlığı altında ilk olarak seçmenlerin siyasal kimlikleri mercek altına alınmıştır. Siyasal eğilimle ilgili soruya seçmenlerin \%39,7’si hiçbiri cevabını vermiştir. Katılımcıların \%37,8'i kendisini merkez sağ olarak tanımlarken; \% 13,5’i radikal sağda yer aldığını ifade etmiştir. Merkez sol olarak tanımlayanların oranı \% 6,5 şeklindeyken; radikal sol olarak tanımlayanların oranı \% 2,5'dir. Sonuç olarak katılımcıların önemli bir kısmı bu soruya çekimser kalırken; büyük bir bölümü de kendisini merkez sağda konumlandırmaktadır.

Tablo 1: Katılımcıların Partiye Bağlılık Düzeylerinin Merkezi Eğilim İstatistikleri

\begin{tabular}{|l|c|c|c|c|c|}
\hline & N & Çok Zayıf & Çok Güçlü & $\overline{\mathbf{x}}$ & SD \\
\hline Partiye Bağlılık Düzeyi & 600 & 1 & 10 & 6,64 & 3,20 \\
\hline
\end{tabular}

Araștırmada seçmenlerin parti bağlılıklarını belirlemek üzere 1 ile 10 arasında puan vermelerine yönelik bir skaladan (1= çok zayıf, $10=$ çok güçlü) yararlanılmıştır. 600 kişinin verdiği cevaplar doğrultusunda yapılan betimleyici istatistik analizi sonuçları; katılımcıların ortanın üzerinde, güçlüye yakın $(\bar{X}=6,64)$ parti bağlılığına sahip olduklarını göstermektedir. 
Tablo 2: Katılımclların Ülke Sorunlarına Karșı İlgi Düzeylerinin Merkezi Eğilim İstatistikleri

\begin{tabular}{|l|c|c|c|c|c|}
\hline & N & Çok İlgisiz & Çok ilgili & $\overline{\mathbf{x}}$ & SD \\
\hline Ülke Sorunlarına Karşı İlgi Düzeyi & 600 & 1 & 10 & 8,60 & 1,97 \\
\hline
\end{tabular}

Yine katılımcıların ülke sorunlarına ilgi düzeylerini belirlemek üzere; 1 ile 10 arasında puan vermelerine yönelik bir skala ( 1 = çok ilgisiz, $10=$ çok ilgili) oluşturulmuştur. Seçmenin verdiği cevaplar incelendiğinde; katılımcıların ülke sorunlarına karşı ilgi düzeylerinin yüksek $(\overline{\mathrm{X}}=8,60)$ olduğu dikkat çekmektedir.

Tablo 3: Siyasal Kampanya ve Konulara İlgi Düzeyinin Merkezi Eğilim İstatistikleri

\begin{tabular}{|l|c|c|c|c|c|}
\hline & N & Çok illgisiz & Çok ilgili & $\overline{\mathbf{x}}$ & SD \\
\hline Siyasal Kampanya ve Konulara İlgi Düzeyi & 600 & 1 & 10 & 5,69 & 3,14 \\
\hline
\end{tabular}

Katılımcılara, "Seçim dönemlerinde siyasal kampanya ve konulara ilgi düzeyiniz nedir?" sorusu yöneltilerek; 1 ve 10 arasında ișaretleme yapmaları istenmiștir. Merkezi eğilim istatistiksonuçları; Konya merkezde yaşayan seçmenlerin referandum sürecinde siyasal kampanya ve konulara ilgilerinin, orta düzeyde $(5,69)$ olduğuna işaret etmektedir.

Öte yandan bu araştırma kapsamında katılımcıların oy verme davranışlarında etkili olan faktörler de incelenmiştir.

Tablo 4: Oy Verme Davranışı Üzerinde Etkili Faktörlerin Merkezi Eğilim İstatistikleri

\begin{tabular}{|l|c|c|c|c|c|}
\hline & N & $\begin{array}{c}\text { Cok } \\
\text { etkisiz }\end{array}$ & $\begin{array}{c}\text { Cok } \\
\text { etkili }\end{array}$ & $\overline{\mathbf{x}}$ & SD \\
\hline Parti lideri & 600 & 1 & 5 & 4,14 & 1,16 \\
\hline Ülkede Meydana Gelen Olay ve Gelişmeler & 600 & 1 & 5 & 4,11 & 1,14 \\
\hline İdeoloji & 600 & 1 & 5 & 4,04 & 1,12 \\
\hline Din ve İnanç Sistemi & 600 & 1 & 5 & 3,89 & 1,31 \\
\hline Adayın Partisi & 600 & 1 & 5 & 3,78 & 1,28 \\
\hline Ekonomik Kazanımlar & 600 & 1 & 5 & 3,63 & 1,38 \\
\hline Aile & 600 & 1 & 5 & 3,16 & 1,39 \\
\hline Geçmiş Dönemde Oy Verilen Parti ya da Aday & 600 & 1 & 5 & 3,06 & 1,39 \\
\hline Siyasal Kampanya Faaliyetleri & 600 & 1 & 5 & 3,02 & 1,34 \\
\hline Etnik Yapı (Türk- Kürt Ayrımı vb.) & 600 & 1 & 5 & 2,94 & 1,47 \\
\hline Yakın Çevre & 600 & 1 & 5 & 2,79 & 1,33 \\
\hline Medya Yayınları & 600 & 1 & 5 & 2,75 & 1,33 \\
\hline Arkadaş Grubu & 600 & 1 & 5 & 2,69 & 1,33 \\
\hline Kamuoyu Araştırma Sonuçları & 600 & 1 & 5 & 2,64 & 1,30 \\
\hline Mensup Olunan ya da İlgi Duyulan Cemaat & 600 & 1 & 5 & 2,48 & 1,45 \\
\hline
\end{tabular}

Tablo 4'te de görüldüğü üzere araștırma sorularına cevap veren seçmenler; parti liderinin $(\bar{X}=4,14)$ oy verme davranışı üzerinde daha etkili olduğuna inanmaktadır. Yine ülkede meydana gelen olay ve gelişmeler $(\bar{X}=4,11)$, ideoloji $(\bar{X}=4,04)$, din ve inanç sistemi $(\bar{X}=3,89)$, adayın partisi $(\bar{X}=3,78)$ ile ekonomik kazanımlar $(\bar{X}=3,63)$, siyasal kararlarda etkili bulunan faktörler arasında yer almaktadır. Bunun yanında mensup olunan ya da ilgi duyulan cemaat $(\overline{\mathrm{X}}=2,48)$, kamuoyu araştırma sonuçları $(\bar{X}=2,64)$ ve arkadaş grubu $(\bar{X}=2,69)$, Konya'da ikamet eden seçmenler tarafindan oy verme davranışları üzerinde daha az etkili görülen faktörler olarak dikkat çekmektedir. Bu sonuçlar; Balcı ve Bal $(2017,482)$ 'ın Konya örneğinde yaptıkları alan araştırmasının sonuçları ile tutarlılık göstermektedir. 


\subsection{Siyasal Bilgilenmede Medya Türlerinin Etki Düzeyleri}

Siyasal bilgilenme süreçlerinde medya türlerinin etki düzeyleri arasında karşılaştırma yapmak amacıyla betimleyici istatistik sonuçlarından yararlanılmıştır.

Tablo 5: Siyasal Bilgilenmede Medya Türlerinin Etki Düzeylerinin Merkezi Eğilim İstatistikleri

\begin{tabular}{|l|c|c|c|c|c|}
\hline Medya Türleri & N & Çok Etkisiz & Çok Etkili & $\overline{\mathbf{x}}$ & SD \\
\hline Televizyon & 600 & 1 & 5 & 3,96 & 1,14 \\
\hline İnternet & 600 & 1 & 5 & 3,71 & 1,24 \\
\hline Sosyal Medya & 600 & 1 & 5 & 3,51 & 1,42 \\
\hline Gazete & 600 & 1 & 5 & 2,95 & 1,29 \\
\hline Radyo & 600 & 1 & 5 & 2,77 & 1,30 \\
\hline Dergi & 600 & 1 & 5 & 2,26 & 1,22 \\
\hline
\end{tabular}

Bunagöre araştırma sorusuna cevap veren katılımcıların, siyasal bilgilenme sürecinde en çok etkilendiği medya türleri arasında televizyon $(\bar{X}=3,96)$ ve internet $(\bar{X}=3,71)$ ilk sıralarda yer almaktadır. Özellikle internet, iletişim maliyetlerini düşürmekte, bilgiye erişimi artırmakta, yeni aktivistler"i güçlendirerek, siyasal bilgilenme ve katılım için yeni fırsatlar yaratmaktadır (Willnat et al., 2013, 562). İnternet aynı zamanda kullanıcı motivasyonlarını güçlendirme yönünde de bir etkiye sahiptir. Aritmetik ortalama değeri açısından en az etkilenilen medya türleri ise dergi $(\overline{\mathrm{X}}=$ $2,26)$ ve radyo $(\bar{X}=2,77)$ olmuştur.

Tablo 6: Siyasal Bilgilenmede Medya Türlerinin Etki Düzeyleri Arasındaki İlişkiye Yönelik Korelasyon Analizi Bulguları (Pearson r)

\begin{tabular}{|c|c|c|c|c|c|c|}
\hline Medyası Türleri & 1 & 2 & 3 & 4 & 5 & 6 \\
\hline 1. Televizyon & 1 & & & & & \\
\hline 2. Gazete &, $427^{\star \star}$ & 1 & & & & \\
\hline 3. Radyo &, $393^{\star \star}$ &, $686^{\star \star}$ & 1 & & & \\
\hline 4. Internet &, $302^{\star *}$ &, $463^{\star \star}$ &, $374^{\star \star}$ & 1 & & \\
\hline 5. Dergi &, $162^{\star \star}$ &, $567^{\star \star}$ &, $493^{\star \star}$ &, $371^{\star \star}$ & 1 & \\
\hline 6. Sosyal Medya &, $306^{\star \star}$ & $420^{\star \star}$ & ,270** &, $663^{\star \star}$ &, $404^{\star *}$ & 1 \\
\hline
\end{tabular}

Siyasal bilgilenmede medya türlerinin etki düzeyleri arasındaki ilişkiyi tespit etmeye yönelik Korelasyon Analizi bulguları incelendiğinde; en güçlü ilişkinin radyo ve gazete arasında yaşandığ dikkat çekmektedir $(r=, 686 ; \mathrm{p}<.01)$. Yine araştırma katılan seçmenlerin siyasal bilgilenme sürecinde interneti etkili görme eğilimi arttıkça, sosyal medyayı etkili görme eğiliminde de bir artış yaşanmaktadır $(r=, 663$; $\mathrm{p}<.01$ ). Diğer yandan siyasal bilgilenmede televizyonun etki düzeyi ile derginin etki düzeyi arasında pozitif yönde oldukça zayıf anlamlı ilişki bulunmaktadır $(r=, 162 ; \mathrm{p}<.01)$. 
Tablo 7: Siyasal Bilgilenmede Medya Türlerinin Etki Düzeyi ile Siyasal Kampanya ve Konulara İlgi Düzeyi Arasındaki İlişkiyi Belirlemeye Yönelik Korelasyon Analizi Bulguları

\begin{tabular}{|l|c|}
\hline Medya Türleri & Siyasal Kampanya ve Konulara İIgi Düzeyi \\
\hline Televizyon &, $149^{\star \star}$ \\
\hline Gazete &, $169^{\star \star}$ \\
\hline Radyo &, $112^{\star \star}$ \\
\hline İnternet &, $211^{\star \star}$ \\
\hline Dergi &, $203^{\star \star}$ \\
\hline Sosyal Medya &, $249^{\star \star}$ \\
\hline
\end{tabular}

Not: ${ }^{* *} p<.01$

Siyasal bilgilenmede medya türlerinin etki düzeyleri ile siyasal kampanya ve konulara ilgi düzeyi arasındaki ilişki incelendiğinde; televizyon $(r=, 149 ; \mathrm{p}<.01)$, gazete $(r=, 169 ; \mathrm{p}<.01)$, radyo $(r=, 112 ; \mathrm{p}<.01)$, internet $(r=, 211 ; \mathrm{p}<.01)$, dergi $(r=$ ,203; $\mathrm{p}<.01)$ ve sosyal medyanın $(r=, 249 ; \mathrm{p}<.01)$ etki düzeyi ile siyasal kampanya ve konulara ilgi düzeyi arasında pozitif yönde zayıf anlamlı ilişki ön plana çıkmaktadır. Bir başka ifadeyle; siyasal kampanya ve konulara ilgi düzeyi arttıkça, internet, sosyal medya, dergi, gazete, televizyon ve radyonun siyasal bilgilenme sürecinde etkili olduğuna duyulan inançta da bir artış yaşanmaktadır.

Tablo 8: Siyasal Bilgilenmede Medya Türlerinin Etki Düzeyi ile Parti Bağlllık Düzeyi Arasındaki İlişkiyi Belirlemeye Yönelik Korelasyon Analizi Bulguları

\begin{tabular}{|l|c|}
\hline Medya Türleri & Parti Bağlılık Düzeyi \\
\hline Televizyon &, $185^{\star \star}$ \\
\hline Gazete &, $091^{\star}$ \\
\hline Radyo & 031 \\
\hline İnternet &, $106^{\star \star}$ \\
\hline Dergi & 071 \\
\hline Sosyal Medya &, $197^{\star *}$ \\
\hline
\end{tabular}

Not: ${ }^{* *} p<.01,{ }^{*} p<.05$

Öte yandan siyasal bilgilenmede medyanın etki düzeyleri ile parti bağlılık düzeyi arasındaki ilişki mercek altına alındığında; televizyon $(r=, 185 ; \mathrm{p}<.01)$, gazete $(r=$ $, 091 ; \mathrm{p}<.05)$, internet $(r=, 106 ; \mathrm{p}<.01)$ ve sosyal medyanın $(r=, 197 ; \mathrm{p}<.01)$ etki düzeyi ile seçmenlerin parti bağlılıkları arasında pozitif yönde zayıf anlamlı ilişki dikkat çekmektedir.

\subsection{Eğitime Göre Siyasal Bilgilenmede Medya Türlerinin Etki Düzeyleri}

Son olarak katılımcıların eğitim düzeyine göre siyasal bilgilenmede medya türlerinin etki düzeyi arasındaki ilişki mercek altına alındığında; anlamlı farklılık, gazete $(\mathrm{F}=2,70 ; \mathrm{p}<$ .05) ve internet $(\mathrm{F}=2,77 ; \mathrm{p}<.05)$ açısından söz konusudur. 
Tablo 9: Katılımcıların Eğitim Düzeyine Göre Siyasal Bilgilenmede Medya Türlerinin Etki Düzeyindeki Farklılık (ANOVA)

\begin{tabular}{|c|c|c|c|c|c|}
\hline & Sum of Squares & df & Mean Square & $\mathbf{F}$ & Sig. \\
\hline \multirow{3}{*}{ Televizyon } & 8,906 & 5 & 1,781 & 1,357 & ,239 \\
\hline & 779,492 & 594 & 1,312 & & \\
\hline & 788,398 & 599 & & & \\
\hline \multirow{3}{*}{ Gazete } & 22,529 & 5 & 4,506 & 2,708 & ,020 \\
\hline & 988,344 & 594 & 1,664 & & \\
\hline & 1010,873 & 599 & & & \\
\hline \multirow{3}{*}{ Radyo } & 5,852 & 5 & 1,170 & ,683 & ,636 \\
\hline & 1017,667 & 594 & 1,713 & & \\
\hline & 1023,518 & 599 & & & \\
\hline \multirow{3}{*}{ İnternet } & 21,300 & 5 & 4,260 & 2,779 & , 017 \\
\hline & 910,534 & 594 & 1,533 & & \\
\hline & 931,833 & 599 & & & \\
\hline \multirow{3}{*}{ Dergi } & 14,230 & 5 & 2,846 & 1,896 & ,093 \\
\hline & 891,688 & 594 & 1,501 & & \\
\hline & 905,918 & 599 & & & \\
\hline \multirow{3}{*}{ Sosyal medya } & 12,581 & 5 & 2,516 & 1,238 & ,290 \\
\hline & 1207,359 & 594 & 2,033 & & \\
\hline & 1219,940 & 599 & & & \\
\hline
\end{tabular}

Yüzde 5 anlamlılık düzeyinde Tukey Testi sonuçları incelendiğinde; lisansüstü ( $\bar{X}=$ $3,25)$ ve lisans $(\bar{X}=3,08)$ eğitimine sahip olanlar; okuryazarlara $(\bar{X}=1,66)$ göre, gazeteden siyasal bilgilenmede daha çok etkilenmektedirler. Yine eğitim düzeyi arttıkça, siyasal bilgilenmede gazetenin etkinliği de artış göstermektedir. Benzer şekilde lisans $(\bar{X}=3,80)$ ve lisansüstü eğitimliler $(\bar{X}=4,04)$, ortaokul mezunlarına $(\bar{X}=3,31)$ göre internetten siyasal bilgilenmede daha çok etkilenmektedirler. Ĕgitim düzeyi artışı, siyasal bilgilenmede internetin etkili olduğunu düşünme yönündeki eğilimleri de artırmaktadır.

\section{Sonuç ve Tartışma}

Medya, kamu politikası ve siyaset hakkındaki düşüncelerin topluma yayılmasında her zaman önemli bir rol oynamaktadır. Dünya genelinde politik aktörler ve hükümetler, hem halkı hem de kendi taraftarlarını bilgilendirmek ve bu suretle kamu hayatını şekillendirmek için, medyadan yoğun bir şekilde yararlanmaktadırlar. Kullanımları ne olursa olsun, medya platformlarında bilgiler hızlı bir şekilde dağıtabilir, kendilerini çoğaltabilir ve insan bizzat kendisi kaynak olarak siyasal bilginin yayılmasında aktif rol oynayabilir. Seçim dönemi gibi siyasal bilginin daha çok dolaşıma sokulduğu ve insanların daha fazla bilgilenmeye ihtiyaç duyduğu bir zaman dilimi için medyanın önemi gittikçe artmaktadır.

İște bu anlayıștan yola çıkarak Konya örneğinde bir saha araştırması gerçekleştirilmiştir. Araştırmada öncelikle seçmenlerin siyasal tutum ve davranışları mercek altına alınmıştır. Katılımcıların oy verme davranışlarında en etkili faktör olarak, parti lideri ve ülkede meydana gelen olay ve gelişmeler ilk sıralarda yer almaktadır. Mensup olunan ya da ilgi duyulan cemaat ve kamuoyu araștırma sonuçları; katılımcıların oy verme davranışlarında en az etkili olduğu düşünülen faktörler konumundadır. 
Katılımcıların siyasal bilgilenme süreçlerinde etkili olan medya türleri incelendiğinde; televizyon ve internetin ilk sıralarda yer aldığı sonucuna ulaşılmıștır. Bir diğer ulaşılan sonuç, katılımcıların siyasal bilgilenme süreçlerinde dergi ve radyonun nispeten daha az bir etkisinin olduğudur. Araștırma katılan seçmenlerin siyasal bilgilenme sürecinde interneti etkili görme eğilimi arttıkça, sosyal medyayı etkili görme eğiliminde de bir artış yaşanmaktadır.

$\mathrm{Bu}$ araştırmada Konya'daki seçmenlerin siyasal tutum ve davranışlarına ilişkin değerlendirmelere de yer verilmiștir. Buna göre katılımcıların oy vermeyi düşündükleri partiye bağlılık dereceleri güçlüye yakındır. Ülke sorunlarına karşı ilgi düzeyleri yüksektir. Siyasal kampanya ve konulara ilgileri de orta düzeydedir. Siyasal kimlikle ilgili soruya katılımcıların önemli bir kısmı çekimser kalırken; büyük bir kısmı da kendisini sağda konumlandırmaktadır. Araştırma sorularına cevap verenlerin 16 Nisan 2017 Anayasa Değişikliği Referandumu sürecinde siyasal kampanya ve konulara ilgi düzeyi arttıkça, internet, sosyal medya, dergi, gazete, televizyon ve radyonun siyasal bilgilenme sürecinde etkili olduğuna duyulan inanç da bir artış yaşanmıștır. Benzer şekilde siyasal bilgilenmede televizyon, gazete, internet ve sosyal medyanın etki düzeyi ile seçmenlerin parti bağlılığı arasında pozitif yönde zayıf anlamlı ilişki bu araştırma ile tespit edilmiştir.

Öte yandan katılımcıların eğitim durumuna göre, siyasal bilgilenmede medya türlerinin etki düzeyindeki anlamlı farklılık, gazete ve internet açısından söz konusudur. Eğitim düzeyi arttıkça, siyasal bilgilenmede gazetenin etkinliği de artmaktadır. Eğitim düzeyi yüksek olan kişiler 2017 Referandumu sürecinde daha çok bir arayışı içerisine girmişler, bu noktada ayrıntıya daha fazla yer veren gazeteleri dana etkili görmüşlerdir. Benzer şekilde eğitim düzeyi artışı, siyasal bilgilenmede internetin etkili olduğunu düşünme yönündeki eğilimleri güçlendirmektedir. Son dakika gelişmelerini ve siyasi tartışları hızlı ve zahmetsiz olarak sunma özelliğine sahip olan internet; eğitim durumu yüksek olanlar açısından daha detaylı siyasal bilgi arayışında önemli imkânlar sunmaktadır.

Sonuç olarak bu araştırma; Konya'da yaşayan insanların 16 Nisan 2017 Anayasa Değișikliği Referandumu sürecinde siyasal bilgilenmelerinde medyanın etkinliği ile eğitim düzeyine göre karşılaştırmalar ortaya koymak amacıyla yapılmıştır. Literatür tarandığında bu konudaki çalışmaların azlığı dikkat çekmektedir. Karşılaştırmalar yapmak ve farklılıkları ortaya koymak adına gelecekteki araștırmalar daha geniş bir örneklemeye giderek, Türkiye'nin farklı bölgelerinde yürütülebilir.

\section{Kaynakça}

Arklan, Ü. ve Karakoç, E. (2013). Medyanın Genel ve Siyasal Gündeme İlișkin Bilgi Edinme Aracı Olarak Kullanımı: Görgül Bir Araştırma, Selçuk Üniversitesi Türkiyat Araştırmaları Enstitüsü, Türkiyat Araştırmaları Dergisi, 33, 325- 363.

Aziz, A. (2003). Siyasal İletişim, Ankara: Nobel Yayın.

Balcı, Ş. ve Akar, H. (2010). Siyasal Bilgilenmede İletişim Araç ve Yöntemlerinin Önem Düzeyi: 29 Mart 2009 Yerel Seçimleri Konya Araştırması. E-Journal of New World Sciences Academy Humanities, 5 (2), 282-305.

Balcı, Ş. ve Bal, E. (2017). Dini ve Ahlaki Değerlerin Oy Verme Davranışı Üzerindeki Etkinliği: "Cinsiyetler Arası Karşılaştırma”. Bünyamin Ayhan vd. (Eds), Sosyal ve Beșeri Bilimler Araştırmaları 2017, Konya: Çizgi Kitabevi Yayınları, 478-487. 
Balcı, Ş. ve Bor, T. (2015). Siyasal Bilgilenmede Televizyonun Önem Düzeyi. Global Media Journal TR Edition, 5 (10): 47-70.

Balcı, Ş. ve Tarhan, A. (2007). Siyasal Bilgilenme ve İnternet: 22 Temmuz 2007 Genel Seçimleri'nde Bir Kullanımlar ve Doyumlar Araştırması. Medya ve Siyaset Uluslararası Sempozyumu, Cilt 1, Ege Üniversitesi İletişim Fakültesi, 15-17 Kasım, İzmir, 322-335.

Balcı, Ş. (2016). Siyasal Karar Verme ürecinde İletişim Araç ve Yöntemlerinin Etki Düzeyleri: "7 Haziran 2015 Genel Seçimleri Örneği”. Şükrü Balcı (Ed.), 7 Haziran'dan 1 Kasım'a Türkiye'de Siyasal İletişim Uygulamaları, Konya: Literatürk Yayınevi, 71-108.

Balcı, Ş., Damlapınar, Z., Pınarbaşı, T. E. ve Astam, F. K. (2016). Siyasal Bilgilenmede Medyanın Rolü ve Etkinliği: Üniversite Öğrencileri Araştırması. Internatıonal Journal of Social Science, 53, 111-126.

Balcı, Ş., Tarhan, A. ve Bal, Enes (2013). Medya ve Siyasal Katılım, Konya: Literatürk Yayınevi

Becker, L. B. ve Dunwoody, S., (1982). Media Use, Public Affairs Knowledge and Voting in a Local Election, Journalism Quarterly, 59 (2), 212-218.

Bekiroğlu, O. ve Bal, E. (2014). Siyasal Reklamcılık, Konya: Literatürk Yayınları.

Bolce, L.; De Maio, G. ve Muzzio, D. (1996). Dial-In Democracy: Talk Radio and the 1994 Election, Political Science Quarterly, 111 (3), 457-481.

Chaffee, S. ve Frank, S. (1996). How Americans get political information: Print versus broadcast news. ANNALS of the American Academy of Political and Social Science, 546 (1), 48-58.

Chaffee, S. H.; Zhao, X. ve Leshner, G. (1994). Political knowledge and the campaign media of 1992. Communication Research, 21, 305-324.

Damlapınar, Z. ve Balcı, Ş. (2014). Siyasal İletişsim Sürecinde Seçimler, Adaylar, İmajlar, Konya: Literatürk Yayınları.

Dimitrova, D. V.; Shehata, A., Strömbäck, J. ve Nord, L. W. (2014). The Effects of Digital Media on Political Knowledge and Participation in Election Campaigns: Evidence from Panel Data. Communication Research, 41 (1), 95-118.

Doğan, A. ve Göker, G. (2013a). Yerel Seçimlerde Seçmen Tercihi (Elazığ Seçmeni Örneği). Adem Doğan ve Göksel Göker (Eds.), Siyasal İletişim Araştırmaları, Ankara: Nobel Akademik Yayıncılık Eğitim Danışmanlık, 23-58.

Doğan, A. ve Göker, G. (2013b). Genel Seçimlerde Seçmen Tercihi: 12 Haziran 2011 Genel Seçimleri Örnek Olayı (Seçim Öncesi 2 Araştırma ve Seçim Sonuçlarının Karşılaştırılması). Adem Doğan ve Göksel Göker (Eds.), Siyasal İletişim Araştırmaları, Ankara: Nobel Akademik Yayıncılık Eğitim Danışmanlık, 109-136.

Drew, D. ve Weaver, D. H. (1998). Voter learning in the 1996 presidential election: Did the media matter?. Journalism ve Mass Communication Quarterly, 75, 292301.

Eveland, W. P. (2004). The Effect of Political Discussion in Producing Informed Citizens: The Roles of Information, Motivation, and Elaboration, Political 
Communication, 21 (2), 177-193.

Fidan, Z. (2016). Teknoloji ve Siyasal İletişim, Konya: Literatürk Yayınları.

Gülmen, Y. (1979). Türk Seçmen Davranışı: 1960-1970, İstanbul: İstanbul Üniversitesi İktisat Fakültesi Yayınları.

Güneș, S. (1996). Medya ve Siyasal Bilgilenme. Yeni Türkiye Dergisi Medya Özel Sayısı, 2 (11): 803-825.

Güz, N. (1995). Siyasal Tercihleri Belirlemede Kitle İletişim Araçlarının Rolü (Mart 1994 Yerel Seçimleri Ankara Örneği). Amme İdaresi Dergisi, 28 (1), 113-128.

Kalaycıoğlu, E. (1983). Karşıllaştırmalı Siyasal Katılma, Siyasal Eylemin Kökenleri Üzerine Bir İnceleme, İstanbul: İstanbul Üniversitesi Yayınları.

Kışlalı, A. T. (2000). Siyasal Sistemler: Siyasal Çatışma ve Uzlaşma. Ankara: İmge Kitabevi.

Kışlalı, A. T. (2002). Siyaset Bilimi. Ankara: İmge Kitabevi.

Koçak, M. C. (2014). Siyasal Bilgilenme Sürecinde Televizyonun Rolü ve Etkileri (Konya Örneği), Yayınlanmamış Yüksek Lisans Tezi, Selçuk Üniversitesi Sosyal Bilimler Enstitüsü, Konya.

Özkan, A. (2004). Siyasal İletişim: Partiler, Seçimler, Stratejiler. İstanbul: Nesil Yayınları.

Scheufele, D. A. (2002). Examining differential gains from mass media and their implications for participatory behavior. Communication Research, 29 (1), 4665.

Tokgöz, Oya (2008). Siyasal İletişimi Anlamak, Ankara: İmge Kitabevi.

Wei, R. ve Lo, V. (2008). News media use and knowledge about the 2006 U.S. midterm elections: Why exposure matters in voter learning. International Journal of Public Opinion Research, 20, 347-362.

Willnat, L.; Wong, J., Tamam, E. ve Aw, A. (2013). Online Media and Political Participation: The Case of Malaysia, Mass Communication and Society, 16, 557-585.

Zhao, X. ve Chaffee, S. H. (1995). Campaign advertisements versus television as sources of political issue information. Public Opinion Quarterly, 59 (1), 41-65. 
